\title{
Structure and Diversity of Homegarden Agroforestry in Thakurgaon District, Bangladesh
}

\author{
Sourovi Zaman ${ }^{*}, 1$, Salah Uddin Siddiquee ${ }^{2}$ and Masato Katoh ${ }^{1}$ \\ ${ }^{I}$ Forest Measurement and Planning Laboratory, Forest Science Department, Agriculture Faculty, Shinshu University, \\ 8304, Minami-minowa, Kami-ina, Nagano-399-4598, Japan \\ ${ }_{2}^{2}$ Insect Ecology Laboratory, Entomology Department, Agriculture Faculty, Shinshu University, 8304, Minami-minowa, \\ Kami-ina, Nagano-399-4598, Japan
}

\begin{abstract}
The study focused on the composition, structure of homegarden, diversity of plant species and contribution of homegarden to household food security, conservation of plant species, socio-economic importance and the constraints of the total production system. Using a structured questionnaire, formal and informal interviews and field observations collected the information. Some information was also gathered by group discussion with the farmers and the information was analyzed by using descriptive statistics. The homegardensize in average in the study area increased with the size of total land holding. A total of 37 useful plant species were identified from the homegardens in Thakurgaon. Diversity and abundance of fruit tree species were found higher in all farm categories followed by timber and fuel wood species. Total income was found higher in large farm category than that of marginal. Mango and jackfruit were identified as an important cash-growing crop in the study area. Tree management practices and the scopes were very common. The farmer faced many problems during tree plantation and the major cause was the animal. Insect was also another common constraint. The homegardens and its management can be improved by proper management practices, more research, cooperative and extension services.
\end{abstract}

Keywords: Homegarden, diversity, household, Bangladesh.

\section{INTRODUCTION}

With about 153 million people on 14.7 million hectares, Bangladesh is one of the most densely populated countries. Over two-thirds of the total land is cultivable and the percentage is shrinking with the rapid growth of population. In Bangladesh, the need for maintaining the population-foodnutrition balance can hardly be overemphasized. Agriculture land is the most basic resource in Bangladesh - the main component for crop production. The current land/person ratio is very unfavorable, and there is little or no scope of expanding the land resource base. In 2003, the per capita land availability was 0.10 hectares, declining from 0.14 hectares in 1992 [1], which puts heavy pressure on land for human habitation and crop production.

A homestead in Bangladesh is an integrated production system and a stable ecosystem that maintains the diversity of life as well as the biological wealth. It is the main source of food, fruits, vegetables, timber and fuelwood for the household and is a reliable source of household income. Shortage of fuel was common irrespective of farm size but it was more acute in the smaller farm categories. About $75 \%$ timber demand and $85 \%$ of fuelwood demand are met by homestead production. It was estimated that about $10 \%$ of the standing volume of wood on homesteads is removed

Address correspondence to this author at the Forest Measurement and Planning Laboratory, Forest Science Department, Agriculture Faculty, Shinshu University, 8304, Minami-minowa, Kami-ina, Nagano-399-4598, Japan; Tel/Fax: 81-265-77-1642; E-mail: sourovi_zamanbd@yahoo.com every year, indicating that homestead plantations are under temerendous pressure [2]. Homegarden agroforestry maintains high levels of productivity, stability and equitability. The homestead agroforestry system was very important in the economy of Bangladesh. In a country like Bangladesh [3], homestead areas involve more than threequarters of all agroforestry issues and consequently the term agroforestry is invariably associated with homesteads.

Today there is a consensus of opinion that agroforestry is practiced for a variety of objectives; an interface between agriculture and forestry and encompasses mixed land-use practices [4]. These practices have been developed primarily in response to the special needs and conditions of tropical developing countries that have not been satisfactorily addressed no advances in conventional agriculture or forestry. Agroforestry is an integrated approach to land use that is characterized by deliberate maintenance of tress and other woody perennials in fields and pastures.

In this study we mainly tried to investigate the present condition of local farmers, their status, and income and future motives in Thakurgaon. In fact, in Bangladesh, most of the native fruits, vegetables, timber and fuelwood come from the homesteads or marginal lands attached to or near homestead. It has been estimated that 3 million ha of the homestead provided $80 \%$ of fruits and $85 \%$ of fuelwood, as well as timber [5]. Still there is very much shortage of food, nutrients and other forest products. There is absolutely no scope to increase land under forestry/agriculture to fulfill national demands. Increase in the vertical distribution of yield assumes that current resources are not fully utilized e.g. 
available light and water and that synergistic benefits exceed antagonistic effects. Therefore, a well-planned and well managed multi-layered cropping can play a great role in improving homestead production and fruit orchard development in Bangladesh [6]. Multiple cropping especially 'multi-layered homestead production system' should be emphasized. Since the space limitation in the homestead, multi-storied cropping should be encouraged which can produce more economic return per unit area. Without increasing the land area the production of these items may be increased considerably by using management technology of horticulture and agroforestry under multi-storied cropping system [7]. The utilization of land should be done in such a way that also maintains the ecological balance in the region.

The homegarden is also an important source of fuelwood, particularly for poor households, supplying from $40 \%$ to $80 \%$ of the rural need [8]. As we have argued traditional homegarden has many desirable characteristics. Although gross yields per hectare are relatively low, they have tended to function largely outside the market economy to cheaply satisfy a wide variety of domestic needs. The production which is widely shared in the community is an important supplement to diet and income, particularly during the critical time between rice harvests. They are valuable genetic resources and they protect soil erosion. In general, homegardening is a stable and highly sustainable system. Homegarden has been shown to be a source of additional income because the household can sell a portion of the garden's produce, also important in overcoming seasonal availability of foods and promoting household selfsufficiency. The objective of the study was to find out structure and diversity of homegarden of Bangladesh with particular reference to Thakurgaon district.

\section{METHODOLOGY}

\subsection{Location of the Study Area}

Bangladesh is located between $20^{\circ} 34^{\prime}-26^{\circ} 3^{\prime} \mathrm{N}$; and $88^{\circ} 01^{\prime}-92^{\circ} 41^{\prime} \mathrm{E}$. It is bordered by the Bay of Bengal on the South and by India on all other sides along with small part of Myanmar (Fig. 1).

The study area Thakurgaon is located in the Northern part of Bangladesh and covers a total area of $2,497.92 \mathrm{~km}^{2}$. The district has 5 upazillas (administrative entities, sub districts) names- Thakurgaon sadar (proper), Baliadangi, Horipur, Ranishonkoil and Pirgonj and the total population of these 5 thanas was about 1.6 million [9]. The study was

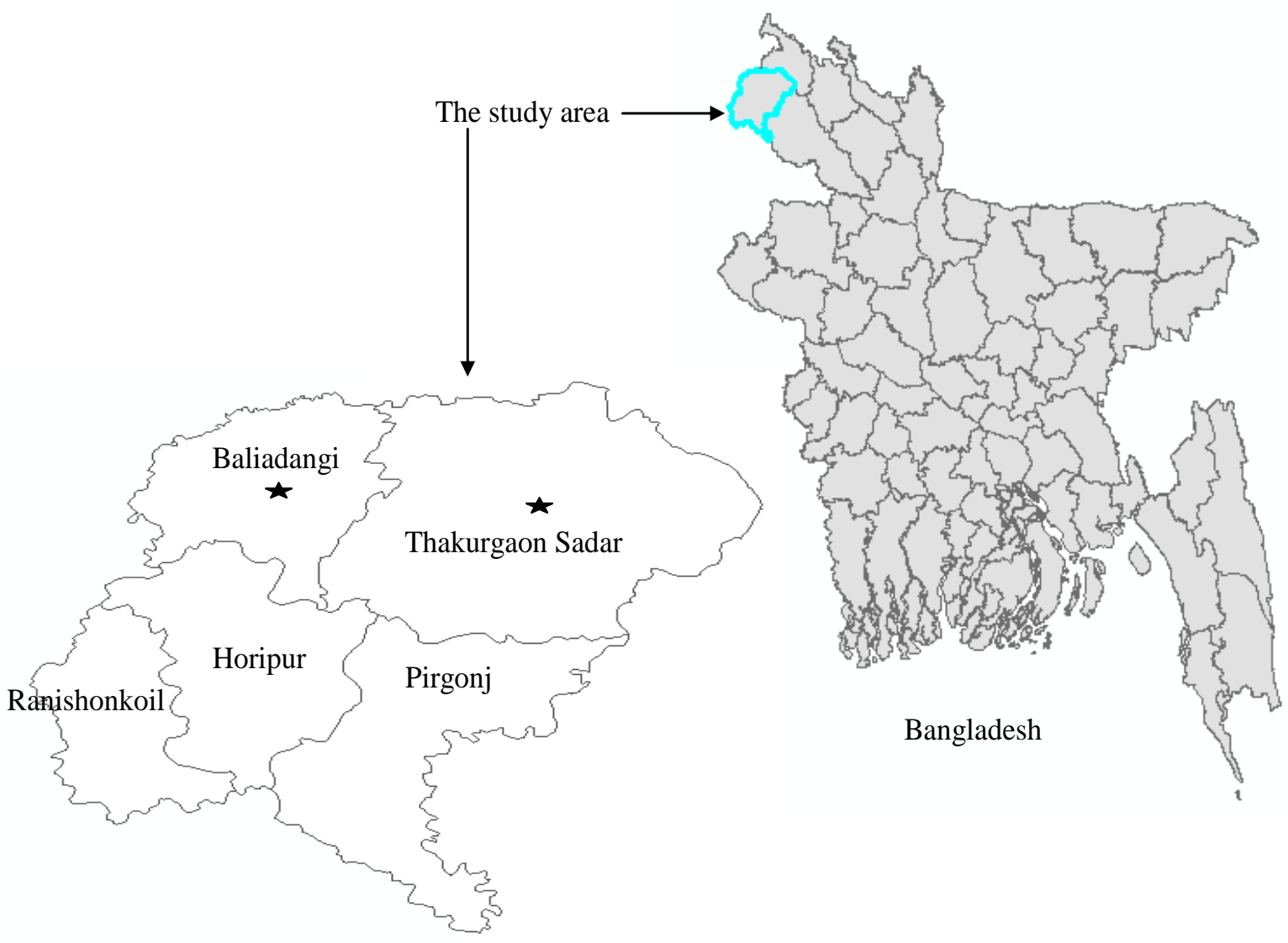

Thakurgaon District

Fig. (1). The study area: Thakurgaon Sadar* \& Baliadangi* Upazila, Thakurgaon district, Bangladesh. (GIS image, source: Bangladesh Weather Division). 
conducted during May to July 2008 in Thakurgaon district in two upazillas namely Baliadangi and Thakurgaon sadar.

\subsection{Site Selection and Sampling Procedure}

The total 40 households (10 households from each category) were selected from each upazilla. All households were grouped into five farm categories according to size of land holdings i.e. landless, marginal, small, medium and large according to Abedin et al. (1988) shown in Table 1 [10]. The farmers who own land up to 0.2 ha were identified and eliminated from the list. They do not practice agroforestry in their homegardens because most of their lands are occupied by their houses. A sample of 80 households was selected, 40 from 2 upazillas with equal number of household from each farm category by stratified random sampling.

Table 1. Farm Size and Land Holding

\begin{tabular}{|c|c|}
\hline Farm Category & Land Holdings (in Hectare) \\
\hline \hline Landless & $<.20$ \\
\hline Marginal & $.21-.50$ \\
\hline Small & $.51-1.00$ \\
\hline Medium & $1.01-2.00$ \\
\hline Large & $>2.00$ \\
\hline
\end{tabular}

\subsection{Data Collection and Data Analysis}

Information was collected from both primary and secondary sources. These were gathered by survey as well as non survey methods. In order to obtain relevant information the survey sources include interviews through a pre-tested interview schedule by a questionnaire. It contained both open and closed form of questions. The questions were designed in Bengali language. The interview schedule was pre-tested with ten households before it was finalized. The pre-testing facilitated the researchers to examine the suitability of different questions and status of the instrument. The final version of the instrument was done on the basis of validity, suggestions, corrections and comment of the research supervisor and experts. Some data were also collected by farmers' group discussions while non-surveys include the information through field survey, direct observations and secondary sources.

Data for this study were collected by the researcher with the help of Upazilla Extension Officer (UAE) and Block Supervisor (BS) of Department of Agricultural Extension (DAE) and the Forest Department of Thakurgaon. To get valid and pertinent information we made all possible efforts to explain the purpose of the study to the respondents. Appointments with the respondents were made in advance by the help of the local leaders. This helped the researchers to have a friendly orientation to the group members. The interview schedule was administered by the researchers personally to the respondents. The collected data were verified through surveying and discussion with the households.
The species composition of homegarden was noted with the help of the farmers and the assistants. In each garden each specimen of all perennial species with name, age and individual number was recorded by asking the owner of household and counting by authors. Income of each household was categorized into 2 groups; income from crop field and income from homegarden.

At the end of the survey, the relevant information was fed into the computer for analysis.

Qualitative Data Analysis was analysed by using descriptive statistics and presented as means, percentages, frequency distributions, and cross tables.

Quantitative Data Analysis summarized into categories to facilitate statistical analysis. The same statistical package was used and analysed by using means, range, correlations regression.

Chi-Square tests were employed to asses the homogeneity of household responses among the different farm categories.

Collected data were coded for processing and analysis. Survey findings were compared on the basis of farm size categories. Relative prevalence (RP) of tree species was determined by multiplying the number of trees per farm by the percentage of farms containing that species. It was calculated by the following equation.

Relative prevalence $(R P)=n_{i} / A \mathbf{x} f_{i} / F$

where, $\mathrm{n}_{\mathrm{i}}=$ Number of specimen species $\mathbf{i}$ on homegarden, $A$ $=$ Area of homegarden.

$f_{i}=$ Number of homegardens on which species $\mathbf{i}$ is found., $F$ $=$ Total number of homegardens.

\section{RESULTS AND DISCUSSIONS}

\subsection{Demographic and Socio-Economic Characteristics of the Respondents}

\subsubsection{Age of the Respondents}

The age of the respondents ranged from 18-60 years old. On the basis of age groups, the respondents were classified into three categories; young age $(<18$ years old), middle age (19-50 years old) and old age ( $>50$ years old). Number and percentage distribution of farmers according to their age group has been shown in the Table 2 . It is revealed that the majority of the respondents were in the middle age category (71\%). This finding is adequate to the national statistics indicating that the selected homesteads were typical homestead of the country [11].

\subsubsection{Family Size}

Family size of the respondents ranged from 2 to 12 (Table 3). The family size of the respondents was classified into three categories. These were small (2-4 members), medium (5-10 members), and large (more than 10 members). Data presented in the Table 3 indicated that $60 \%$ of the respondents were in medium size family which was also a representative of typical family size in Bangladesh. In Bangladesh it is very common to live together with parents and with brothers and sisters and sometime with relatives 
(Joint family) [11]. It was noted that the percentage of joint families was higher in large farm categories. This might be one of the reasons for larger family size in large farm categories.

Table 2. Age of the Respondents

\begin{tabular}{|c|c|c|}
\hline \multirow{2}{*}{ Category } & \multicolumn{2}{|c|}{ Respondent } \\
\cline { 2 - 3 } & Number & Percent (\%) \\
\hline \hline Young age $(<18$ years $)$ & 10 & 13 \\
\hline Middle age $(19-50$ years $)$ & 57 & 71 \\
\hline Old age $(<50$ years $)$ & 13 & 16 \\
\hline Total & 80 & 100 \\
\hline
\end{tabular}

Table 3. Family Size of the Respondents

\begin{tabular}{|c|c|c|}
\hline \multirow{2}{*}{ Category } & \multicolumn{2}{|c|}{ Respondents } \\
\cline { 2 - 3 } & Number & Percent (\%) \\
\hline \hline 2-4 members (Small) & 21 & 26 \\
\hline $5-10$ members (Medium) & 48 & 60 \\
\hline$>10$ members (Large) & 11 & 14 \\
\hline Total & 80 & 100 \\
\hline
\end{tabular}

\subsubsection{Education}

The levels of education were categorized into four groups. These were illiterate (no schooling), primary level (class I-V), secondary level (class VI-X), and above secondary level (college and university). The range of education level of the respondents ranged from no formal education to above college levels. The level of education of the respondents is shown in Table 4. This observation is also in conformity with national average of education of Bangladesh [12].

\subsubsection{Occupation}

In rural area of Bangladesh maximum number of population are either involved in agriculture. A small portion of the population is engaged in business while some earn their daily life from service in the local area or elsewhere. The occupation of the respondents was classified into four groups. Among the four occupations of the respondents agriculture was the major occupation of the total respondents and was followed by service, business and daily laborer (Table 5).

\subsection{Farm and Homestead Size}

The average size of homegarden was found different within the farm categories. There was strong correlation ( $\mathrm{r}=$ 0.9857 ) between the total land holdings and the homegarden size. The average size of land holding for the large category was 4.798 ha while the land holding for medium, small and marginal farm category was $1.6,0.758$ and 0.327 ha respectively (Table 6). On the other hand, the average homestead size for large category was .33 ha whereas the medium, small and marginal categories were $0.180,0.087$ and 0.066 ha respectively.

Table 4. The Education Level of the Respondents

\begin{tabular}{|c|c|c|}
\hline \multirow{2}{*}{ Category } & \multicolumn{2}{|c|}{ Respondent } \\
\cline { 2 - 3 } & Number & Percent (\%) \\
\hline \hline Illiterate (No schooling) & 16 & 20 \\
\hline Primary level (I-V) & 39 & 49 \\
\hline Secondary level (VI-X) & 19 & 24 \\
\hline Higher educated (College, University) & 6 & 7 \\
\hline Total & 80 & 100 \\
\hline
\end{tabular}

Table 5. Occupation of the Respondents in Different farm Categories

\begin{tabular}{|c|c|c|c|c|c|}
\hline \multirow{2}{*}{ Category } & \multicolumn{5}{|c|}{ \% of the Respondents } \\
\cline { 2 - 6 } & Marginal & Small & Medium & Large & All Farms \\
\hline \hline Agriculture & 49 & 64 & 67 & 69 & 62 \\
\hline Service & 10 & 21 & 20 & 14 & 16 \\
\hline Business & 11 & 15 & 13 & 17 & 14 \\
\hline Daily labor & 30 & 0 & 0 & 0 & 8 \\
\hline
\end{tabular}

\subsection{Livestock}

It was observed from the study that the farmers who won large properties keep more animals than the farmers who won small properties (Table 7). However some households from small and marginal farm categories do not keep animals probably due to shortage of cash to buy the animal and maintenance. Lack of manpower for attending the animals and shortage of grazing land are identified as the mail reasons for those who do not keep livestock. Large animal and poultry farms serve as contingent funds which are easily encased when needed.

Table 6. Farm Size and Homestead Size in Different Farm Categories

\begin{tabular}{|c|c|c|}
\hline \multirow{2}{*}{ Farm Category (N) } & \multicolumn{2}{|c|}{ Average Size (ha.) } \\
\hline & Total Land Holding & Home Garden \\
\hline Large (20) & 4.798 & $0.330(6.88)$ \\
\hline Medium (20) & 1.600 & $0.180(11.25)$ \\
\hline Small (20) & 0.758 & $0.087(11.48)$ \\
\hline Marginal (20) & 0.327 & $0.066(20.18)$ \\
\hline
\end{tabular}

\subsection{Tree Crop Intensity and Association}

It was observed that a great variety of trees were grown and harvested from different homegarden. It was found (Table 8) that total number of other plant species per unit area (ha) of the homegarden was gradually decreasing from marginal farm category (582 plants/ha) to large category 
(368 plants/ha). As the smaller farm category owned small piece of land and the land is a limiting resource, they want to intensify their land by growing more trees in their homegardens for their subsistence. It might be the one of the reasons having more tree crop intensity in smaller farm categories. It was found that the marginal and small farms having less number of bamboo per ha than the larger farm categories. The frequencies of other plant species like banana (Musa spp) and betel nut (Areca catechu) was found higher in the smaller farm categories.

Table 7. Average Number of Livestock in Different Farm Categories (20 Households in Each Category)

\begin{tabular}{|c|c|c|c|c|}
\hline \multirow{2}{*}{ Farm Category } & \multicolumn{4}{|c|}{ Average Number } \\
\cline { 2 - 5 } & Cattle & Goat & Buffalo & Poultry \\
\hline \hline Large & 6.10 & 2.75 & 0.30 & 25.55 \\
\hline Medium & 3.50 & 1.80 & 0.00 & 19.25 \\
\hline Small & 2.45 & 1.70 & 0.10 & 10.65 \\
\hline Marginal & 1.75 & 1.40 & 0.00 & 11.60 \\
\hline
\end{tabular}

One of the major components of homegarden production system was the planting of horticultural and forest species for food, wood, fuel and cash. Different trees were grown in the homegardens which includes mango (Magnifera indica), jackfruit (Artocarpus heterophyluus), banana (Musa spp), coconut (Cocus nucifera), guava (Psidium guajava), neem (Azadirachta indica), shisoo (Dalbargia sissoo), mahogany (Swietenia macrophylla), etc. It was observed that farmers often use trees as trellis to grow some vegetables like yam, country bean, etc. Various shade tolerance and/or shade demanding plants like ginger (Zingiber officinale L), turmeric (Curcuma longa L), pineapple (Ananas comosus L Meer), aroids (Colocasia indica Lour) etc. were found to grow in the homegardens under the shade of the trees. In the study area, different combinations of tree-vegetables associates were recorded (Table 9). A total 31 of vegetables were found to grow in association with trees either under direct shade or as creeper. The finding of present study is similar to the findings by Momin et al. (1990) [13], who mentioned that there are some shade loving crops which grow well under and near by the canopies of trees. They are Zingiber officinale, Annona squamasa, Curcuma longa, Ipomoea batatas, Capsicum frutescens, Colocasia, Xanthosoma, Alocasia, Amorphophallus, Dioscorea, Piper betle, and many vegetables spices.

It was observed that only few large and medium farmers were growing pineapple under the betelnut plants. Only few large and medium farms were found to grow pineapple under betelnut trees. It was a source of extra income for those farms. Usually the farmers' were not growing any crops under the shade of betelnut trees. Lack of proper knowledge and availability of inputs and technology were found as major causes not to practice it.

Table 8. Average Number of Trees (/ha.) According to Species and Farm Categories (Average of 20 Households in Each Category)

\begin{tabular}{|c|c|c|c|c|}
\hline \multirow{2}{*}{$\begin{array}{c}\text { Farm } \\
\text { Category }\end{array}$} & \multicolumn{4}{|c|}{ Average Number of Trees Per Hectare } \\
\cline { 2 - 5 } & Betel Nut & Banana & Bamboo & *Other Plant spp. \\
\hline \hline Large & 282 & 71 & 6430 & 368 \\
\hline Medium & 287 & 75 & 5130 & 345 \\
\hline Small & 236 & 180 & 4975 & 487 \\
\hline Marginal & 390 & 193 & 4310 & 582 \\
\hline
\end{tabular}

*Other plant spp- plant species other than bamboo, banana, and betelnut.

\subsection{Income from Tree and Tree Products}

In Thakurgaon about $55 \%$ of large farms had less than $10 \%$ income from their homegardens whereas no household from the marginal farm category got less than $10 \%$ of their income from homegardens. $40 \%$ of marginal farms got $20-30 \%$ of their income from homegardens whereas no farmer from large farm

Table 9. Crop Associated with Major Tree Species in the Study Area

\begin{tabular}{|c|c|c|c|c|}
\hline \multirow{2}{*}{ Tree Species } & \multicolumn{2}{|c|}{ Vegetables Grown Under Trees } & Creeper Vegetables Grown Using Trees as Trails \\
\cline { 2 - 5 } & Major & Minor & Major & Minor \\
\hline \hline Mango & $\begin{array}{c}\text { Aroids, Amaranthus, Spinach, } \\
\text { Turmeric, Country bean }\end{array}$ & Ginger, Bitter gourd, Cow pea & Sponge gourd, Ribbed gourd & Bitter gourd \\
\hline Jackfruit & $\begin{array}{c}\text { Sweet gourd, Pineapple, Chili, } \\
\text { Turmeric, Aroids }\end{array}$ & $\begin{array}{c}\text { Indian spinach, Red spinach, } \\
\text { Cowpea }\end{array}$ & Sponge gourd, Ribbed gourd & Country bean \\
\hline Coconut & $\begin{array}{c}\text { Amaranthus, Aroids, Spinach, } \\
\text { Turmeric, Radish }\end{array}$ & Pineapple, Egg plant, ginger & Sponge gourd, Betel leaf \\
\hline Jujube & Amaranthus, chili & Spinach, Turmeric, & Country bean & Sweet gourd \\
\hline Banana & Red spinach, Garlic & Potato & Sponge gourd \\
\hline Litchi & Egg plant, Radish & Amaranthus, Radish, Pineapple, & Cucumber \\
\hline Mahogany & Spinach, & Amaranthus, ginger & Sweet gourd & Ribbed gourd \\
\hline Sisso & Turmeric, Amaranthus & Egg plant, Aroids & Sweet gourd, Country bean & Bitter gourd, \\
\hline Guava & Pineapple, ginger & Garlic & Country bean \\
\hline
\end{tabular}


category got more than $20 \%$ of their income from homegardens. The smaller farm category depended more on their homegardens and intensively cultivated by them (Table 10). It might be the reason why they got higher percentage of income from their homegardens. Trees in the homestead generated income to the farmers. The study showed that the average income generated from homestead trees was 22,619 BDT (Bangladesh Taka) per farm. The income of the marginal farmers from trees was much lowers than the income of the other farm categories (Table 10). The lower income of the farmers from tree products was probably due to lower number of trees and land of trees in the homestead.

Table 10. Total Income from Homegarden

\begin{tabular}{|c|c|c|c|c|c|}
\hline \multirow{2}{*}{$\begin{array}{c}\text { Farm } \\
\text { Category }\end{array}$} & \multicolumn{5}{|c|}{ Income Percentage (from Total* Net Income) } \\
\cline { 2 - 6 } & $<\mathbf{1 0}$ & $\mathbf{1 0 - 2 0}$ & $\mathbf{2 0 - 3 0}$ & $>\mathbf{3 0}$ & Income (Taka*/Farm) \\
\hline \hline Large & 55 & 45 & 0 & 0 & 36,237 \\
\hline Medium & 20 & 60 & 15 & 5 & 25,360 \\
\hline Small & 5 & 65 & 30 & 0 & 16,700 \\
\hline Marginal & 0 & 40 & 40 & 20 & 12,180 \\
\hline \multicolumn{6}{|c|}{ Mean income } \\
\hline
\end{tabular}

*Total income $=$ Income from crop field + Income from homegarden.

Bangladeshi Taka $(B D T)=0.0145137$ USD.

\subsection{Relative Prevalence of Tree Species Grown in Homestead}

A total of 37 tree species were identified in the study area. The relative prevalence (RP) of tree species found in the study area is shown Table 11. The most common species like mango, jackfruit, neem and banana were very high while prevalence of less common species like mander, bael and khoksha was found very low. Ecological factor is one of determinant of species grown in the farms. Besides the ecological reasons, the socio-economic condition of the household was also a major determinant of the species-mix prevailing in a homegarden. There were minor differences in relative prevalence of less common species and significant differences of most common species among the farm categories. Clearly farmers of that area prefer some species to grow in their farms. The decision of which trees to grow depends on a combination of price and yield, both depending on the location of the farm in terms of ecological zone and proximity to consumption centre [14].

\subsection{Problems in Tree Establishment Faced by the Farmers}

The major problem faced by the farmers in tree establishment was the damage caused by animals. Animals which are very essential for draft purpose and post harvest operations damaged leaves and branches of trees and crush the seedlings of young trees. Seedlings are also damaged by children and storm. Farmers reported more damage caused by animals and insect pest in the homesteads. Storm was also reported to cause damage to the trees. In the homesteads trees obstructed ventilation or fresh air caused difficulties in post harvest operation of crops and were in some cases a source of conflict with neighbors. Trees also damaged roofs of houses during rain and storm. A few of the farmers said that they had no problem in the homestead.

\section{CONCLUSIONS}

The researchers have studied a large number of individual farms and offered farmers choices in new technologies and production methods developed through location specific research for crops, livestock, fisheries, agroforestry and the homestead. Then they followed up the

Table 11. Relative Prevalence of Tree* in the Homegardens of Different Farm Categories

\begin{tabular}{|c|c|c|c|c|c|}
\hline Species Name Local & Scientific Name & Relative Prevalence & Species Name Local & Scientific Name & Relative Prevalence \\
\hline Horticultural Species & & & Forest Species & & \\
\hline Jackfruit & Artocarpus heterophyluus & 26.28 & Neem & Azadirachta indica & 21.43 \\
\hline Banana & Musa spp. & 25.27 & Sisso & Dalbergia sissoo & 5.36 \\
\hline Guava & Psidium guajava & 7.71 & Raintree & Samania saman & 0.43 \\
\hline Litchi & Litchi chinensis & 5.65 & Kadam & Anthocephallus chinensis & 2.71 \\
\hline Bael & Aegle mermelos & 0.17 & Shimul & Gossypium harbacium & 2.93 \\
\hline Coconut & Cocos nucifera & 9.30 & Tarul & Albizia chinensis & 0.58 \\
\hline Lebu & Citrus limon & 3.11 & Mander & Erythrina variegate & 0.11 \\
\hline Bamboo & Bambusa spp. & 10.23 & Pitrai & Aphanamixis polystachya & 0.67 \\
\hline Betel nut & Areca catechu & 14.32 & Shonalu & Cassia fistula & 1.94 \\
\hline
\end{tabular}


farmers' response and progress. The amount of information generated is so large and complex that researchers need more sophisticated techniques to analyze the data and utilize them meaningfully. The traditional homestead system at Thakurgaon district was found poor in terms of management level in cultural practices. Farmers depend on the naturally growing trees on the homegarden. The modern technologies and extension supports to develop the traditional production systems were almost not available. Increased tree plantation in the homesteads and their appropriate management including intercropping practices should be the strategy for enhancing tree cover of the study area in order to meet basic needs of its people and maintain environmental balance.

To get fruits, fuel wood, timber and various agricultural products as well as to bring back equilibrium in the ecosystem, establishment of multi-layered cropping systems in the homesteads and/or orchard is inevitable. The developed model should be applied in the orchards of jackfruit in central region and forest plantations in forest areas of Bangladesh.

In spite of the immense scope and prospects of the homegardens no systematic program has been undertaken so far to improve the productivity of the homegarden. The homegarden system can be improved by proper care management practice, more research performance, cooperative and extension services etc., and replace low economic value crops by high economic value crops. This will ensure sustainable production for the poor farmers of Bangladesh. Efforts should be made to make the rural farmers aware of the appropriate planning and management of the homesteads and to provide them with necessary training and other technical supports for these purposes. Agro-based industry should be built for more income generating activities. Jackfruit and mango being multi purpose fruit tree commonly found in all locations could provide the basis for food process industry. The efforts should be made to identify different shade tolerant vegetables and to motivate and train the farmers to increase the vegetables production of the study area and to cultivate them under the trees in the homestead. Women work efficiency should be increased by training, education and extension supports since they are mainly involved in home gardening.

To improve the socio-economic conditions of the households, designing of new program to develop the homegarden agroforestry production system in accordance with the farmer's needs, resource base, goals and preferences, and bio-physical setting is an urgent issue. That program can only lead to viable production systems towards sustainable livelihood in the coming future. Increased tree plantation in non-forest area especially in the homegardens should be the strategy for enhancing the tree cover of the country in order to meet demand for food, fuel wood and timber for the households and fodder for the livestock, as well as to maintain the sustainability of production system.

\section{ACKNOWLEDGEMENTS}

The authors express deep sense of gratitude to the stuff of Department of Agricultural Extension (DAE), Forest Department and the farmers of Thakurgaon, Bangladesh for their cooperation during data collection. Also acknowledge the Japanese Ministry of Science and Education (Monbukagaksho MEXT) for financial support to conduct this research. We greatly appreciate the anonymous reviewers for their valuable comments, criticisms and suggestions.

\section{REFERENCES}

[1] BBS. Statistical Pocket Book of Bangladesh. Bangladesh Bureau of Statistics. Ministry of Planning, Dhaka 2004

[2] Haque MA. Homestead agroforestry in Bangladesh. Proceedings of the Symposium on Horticulture in National Development. Bangladesh Horticultural Society. Bangladesh Agricultural University, Mymenshingh 1992; pp. 182-90.

[3] Khaleque K. Homestead forestry practices in Bangladesh. Agroforestry for rural needs. Proceedings of the workshop of the IUFRO project group, India 1987.

[4] Nair PKR. An introduction of homegarden agroforestry. ICRAF, Nairobi 1993; p. 85.

[5] Rahim MA. Horticultural crops and agroforestry in Bangladesh. Proc. Workshop on Agroforestry. GTI, BAU, Mymenshingh 1997; pp. 83-90.

[6] Ahmed M, Ali MH. Agroforestry-environmental linkages and different tree species in homegarden. Lecture note prepared for the Agroforestry Training Workshop held during BARC, Dhaka Feb 27-4 March, 2003; pp. 51-8.

[7] Mallik A-As-Saqui, Ruhul A. Prospect of agroforestry in Bangladesh and Effective Management Systems in the RDRS Area of Northern Bangladesh. In: Hsiung W, Chandler PF, Eds. Agroforestry, Research and Practice. China Forestry Publishing House, Beijing, P.R. China 2001.

[8] Wiersum KF. Indigenous exploitation and management of tropical forest resources an evolutionary continuum in forest-people interaction. Agric Ecosyst Environ 1997; 83(1): 1-16.

[9] Government of Bangladesh. Statistical Pocketbook Bangladesh 2006 Bangladesh. Bureau of Statistics, Ministry of Planning, Dhaka, Bangladesh 2007.

[10] Abedin MZ, Quddus MA. Household fuel situation, homegardens and agroforestry practices at six agro-ecologically different locations of Bangladesh. In: Abedin MZ, Lai CK, Ali MO, Eds. Homestead Plantation and Agroforestry in Bangladesh. Proceedings of a National workshop held Joydebpur, Bangladesh, July 17-19, 1988.

[11] Government of Bangladesh. Prospectus of Traditional homegarden Agroforestry in Bangladesh at a momentary look. Ministry of Environment and Forestry. Dhaka, Bangladesh 2001.

[12] Government of Bangladesh. Statistical Pocketbook Bangladesh 2003. Bangladesh. Bureau of Statistics, Ministry of Education, Dhaka, Bangladesh 2004.

[13] Momin MA, Abedin MZ, Amin MR, Islam QMS, Haque MM Existing homestead plantation and household fuel use pattern in the flood-prone Tangail region of Bangladesh. In: Abedin MZ, Lai CK, Ali MO, Eds. Homestead plantation and agroforestry in Bangladesh. BARI, Joydebpur, Bangladesh 1990; pp. 136-48.

[14] Michon G, Bompard J, Hecketsweiler P, Ducatillion C. Tropical forest architectural analysis as applied to agroforests in the humid tropic: The example of traditional village-agroforests in West Java. Agrofor Syst 1983; 1: 117-29. 